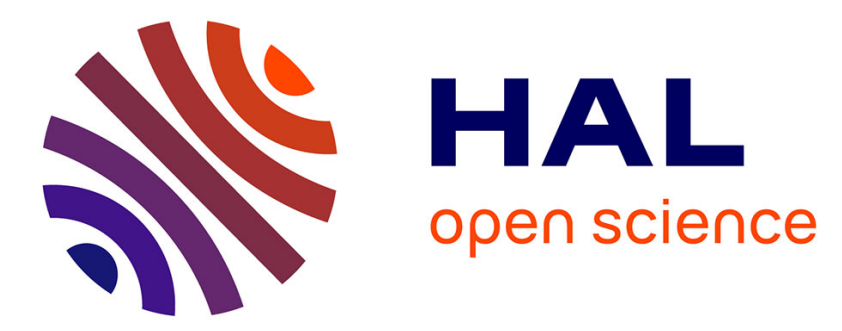

\title{
Fragmentation of foamed silicic melts: an experimental study
}

Caroline Martel, Donald B. Dingwell, Oliver Spieler, Michel Pichavant, Max

Wilke

\section{To cite this version:}

Caroline Martel, Donald B. Dingwell, Oliver Spieler, Michel Pichavant, Max Wilke. Fragmentation of foamed silicic melts: an experimental study. Earth and Planetary Science Letters, 2000, 178, pp.47-58. 10.1016/S0012-821X(00)00062-5 . hal-00115129

\section{HAL Id: hal-00115129 \\ https://hal-insu.archives-ouvertes.fr/hal-00115129}

Submitted on 18 Feb 2013

HAL is a multi-disciplinary open access archive for the deposit and dissemination of scientific research documents, whether they are published or not. The documents may come from teaching and research institutions in France or abroad, or from public or private research centers.
L'archive ouverte pluridisciplinaire HAL, est destinée au dépôt et à la diffusion de documents scientifiques de niveau recherche, publiés ou non, émanant des établissements d'enseignement et de recherche français ou étrangers, des laboratoires publics ou privés. 


\title{
Fragmentation of foamed silicic melts: an experimental study
}

\author{
$\underline{\text { C Martel }}^{\mathrm{a}}, \underline{\text { D.B Dingwell }}{ }^{\mathrm{a}}, \underline{\text { O Spieler }^{\mathrm{a}}}, \underline{\text { M Pichavant }}{ }^{\mathrm{b}}, \underline{\mathrm{M} \text { Wilke }}$ \\ ${ }^{a}$ Bayerisches Geoinstitut, Universität Bayreuth, 95440 Bayreuth, Germany \\ ${ }^{\mathrm{b}}$ CNRS-CRSCM, 1A rue de la Férollerie, 45071 Orléans Cedex 2, France \\ ${ }^{\mathrm{c}}$ Institut für Mineralogie, Universität Hannover, Welfengarten 1, 30167 Hannover, \\ Germany
}

\begin{abstract}
We present the first experimental investigation of the fragmentation behavior of twophase (melt+gas) rhyolitic systems under rapid decompression. Two-phase samples have been generated by foaming water-oversaturated rhyolitic melts up to $900^{\circ} \mathrm{C}$ and up to 18 $\mathrm{MPa}$ prior to rapid decompression in a fragmentation bomb. The fragmented particles or experimental pyroclasts were recovered for analysis. Several features of naturally foamed pumices have been reproduced, including the generation of both isotropic and tube pumices. We focus here on the fragmentation behavior. Fragmentation occurred through a layer-by-layer process, in the brittle regime of melt response. We investigated the influence of the magnitude of the decompression (4 to $18 \mathrm{MPa}$ ), the porosity ( 0 to 85 vol\%) and the pore morphology (tube versus isotropic) on the fragment size distribution. Less vesicular samples (porosity $<50 \mathrm{vol} \%$ ) generate coarser fragments. Highly vesicular samples (porosity $>50 \mathrm{vol} \%$ ) yield coarser fragments when decompressed below $15 \mathrm{MPa}$ and finer fragments when decompressed above $15 \mathrm{MPa}$. Increasing decompression of the vesicular samples results in a decrease in fragment size of $0.2 \Phi$ unit/MPa. The presence of tubes instead of isotropic pores in vesicular samples generates finer fragments under decompression. Implications for dome eruptions are discussed.
\end{abstract}

Keywords : fragmentation; experimental studies; magmas; pyroclastics; size distribution; domes

\section{Introduction}

Explosive silicic eruptions are controlled by a complex interplay of physical and chemical processes, leading to a wide range of eruptive features. Critical to the evaluation of monitoring data and for the development of eruptive scenarios is a realistic and detailed mechanistic picture of silicic eruptions, which are most robust if they can be confirmed by real time experimental investigation of the magma of interest, under realistic pressuretemperature conditions.

Reliable quantification of the parameterization of experimental results on magma fragmentation must be based on a solid foundation of well-characterized materials. We have chosen the best investigated silicate melt system of relevance to the earth sciences, HPG8 haplogranitic melt+water [1], which allow us to specify the physico-chemical properties (e.g. surface tension, viscosity, density, diffusivity) of the magma during the fragmentation event. 
The fragmentation of magma remains hotly debated: there is no general agreement on mechanisms [2], [3], [4] and [5]. The principal fragmentation mechanisms in bubbly melts that have been proposed are gas bubble overpressure exceeding the magma tensile strength and melt film instabilities due to the propagation of a decompression wave.

Fragmentation simulations in laboratories have been performed in shock-tube apparatus, either using liquids at room pressure and temperature or magmas. The former studies [6], [7] and [8] provide the opportunity to observe the dynamics of vesiculation and fragmentation in transparent experimental devices. In the latter studies [9] and [10], natural magmas are rapidly decompressed and the chilled fragmented particles are recovered for characterization. These experimental simulations have been pioneering in nature and are certainly valuable but the time has now come to systematize the nature and efficiency of fragmentation as a function of the physico-chemical state of the magma and the intensive variables operative at the fragmentation event in nature.

We are interested here in the mechanism by which magmas fragment under rapid decompression using the experimental device of [9] and [10]. Two sets of parameters that must be constrained for these simulations are the magnitude of the decompression and the physico-chemical properties of the material prior to fragmentation. As the samples have been foamed under controlled conditions immediately prior to fragmentation, we can compare the influence of porosity, viscosity and decompression on the fragment morphology and size distribution.

\section{Experimental}

\subsection{Fragmentation apparatus}

The fragmentation device is described in [9] and [10]. A high-pressure and high-temperature (HPT, up to $23 \mathrm{MPa}$ and $950^{\circ} \mathrm{C}$ ) section consists of a vertically operating externally heated cold-seal pressure vessel (Nimonic 105 alloy) with a bore of $20 \mathrm{~mm}$ in diameter and $450 \mathrm{~mm}$ in length. Cylindrical samples are placed in the hot source of the HPT section on a top of a Ktype thermocouple (precision of $\pm 1^{\circ} \mathrm{C}$ ). The temperature gradient of a $5 \mathrm{~cm}$ long sample is less than $20^{\circ} \mathrm{C}$ [9]. The average heating rate ranges between $15^{\circ} \mathrm{C} / \mathrm{min}$ at temperatures below $400^{\circ} \mathrm{C}$ and $5^{\circ} \mathrm{C} / \mathrm{min}$ at temperatures above $650^{\circ} \mathrm{C}$. The pressure medium is argon. The pressure is measured by piezoresistive pressure transducers (precision of $\pm 0.2 \mathrm{MPa}$ ). The lowpressure and low-temperature (LPT, room conditions) section is a large cylindrical tank, $2 \mathrm{~m}$ high and $70 \mathrm{~cm}$ wide. The HPT section is sealed and separated from the LPT section by one to three copper or steel diaphragms specially designed to disrupt at a given pressure depending on their thickness.

\subsection{Sample preparation}

A finely ground powder of HPG8 haplogranitic glass $\left(\mathrm{SiO}_{2}: 79.0, \mathrm{Al}_{2} \mathrm{O}_{3}: 12.0, \mathrm{Na}_{2} \mathrm{O}: 4.6\right.$, $\mathrm{K}_{2} \mathrm{O}: 4.2 \mathrm{wt} \%$, microprobe analyses) was loaded with 1.4 to $5.7 \mathrm{wt} \%$ distilled water in platinum capsules of $2 \mathrm{~cm}$ in diameter and $2 \mathrm{~cm}$ in length. Capsules were arc-welded while surrounded by liquid nitrogen to prevent water loss. Melt hydrations were performed in large diameter furnace of an internally heated pressure vessel (IHPV) at CRSCM in Orléans for ca. 1 month at $950^{\circ} \mathrm{C}$ and $120 \mathrm{MPa}$, then isobarically quenched. Smaller samples were prepared in platinum capsules of $8 \mathrm{~mm}$ diameter and $2.5 \mathrm{~cm}$ long, loaded for 4-6 days in a vertically working IHPV at $1000-1100^{\circ} \mathrm{C}$ and $300 \mathrm{MPa}$ at the Mineralogical Institute of the University 
of Hannover. The starting glasses were all crystal-free, but small bubbles were sometimes present (see Table 1 for bubble size and volume). Doubly polished (150-220 $\mu \mathrm{m}$ thick) glass plates prepared from each end of the cylinders were used for the determination of water content by near-infrared spectroscopy (Bruker IFS $120 \mathrm{HR}$ ). The concentrations of $\mathrm{H}_{2} \mathrm{O}$ and $\mathrm{OH}$ species were determined from the height of the absorption bands at 5230 and $4500 \mathrm{~cm}^{-1}$, respectively, by using the Lambert-Beer law and the extinction coefficients of [17]. Water contents between the two ends of the glass cylinders were homogeneous within a range of 0.2 wt $\%$, up to $0.4 \mathrm{wt} \%$ for two samples (Table 1).

\subsection{Vesiculation and fragmentation experiments}

The hydrated glass cylinders were polished to fit tube-shape holders $(8 \mathrm{~mm}$ i.d. and $5 \mathrm{~cm}$ long or $17 \mathrm{~mm}$ i.d. and $25 \mathrm{~cm}$ long), which were loaded inside the HPT section of the fragmentation device. The HPT section was pressurized, then heated up. These conditions were maintained constant for $30 \mathrm{~min}$, so that water exolution from the oversaturated melt is allowed to proceed within 1-2 $\mathrm{h}$ (starting at the glass transition temperature). All the experiments experienced vesiculation and subsequent rapid decompression, except experiments 1 and 2, which were isobarically quenched instead of rapidly decompressed, providing an insight into the pre-fragmentation state. The sequential occurrence of foaming and fragmentation permits the investigation of foamed materials without the potential complications arising from changes in foamed material properties due to an intermediate quenching step.

Some experiments were performed using a single diaphragm, which was disrupted by increasing the pressure in the HPT section up to the diaphragm strength (maximum increase of $4 \mathrm{MPa}$ in less than $5 \mathrm{~s}$ ). During the course of this work we improved the procedure by installing a set of three diaphragms, separated by two small-volume chambers that were independently pressurized. Pressurizing these small-volume chambers over the strength of the diaphragms while pressure is maintained constant in the HPT section leads to the simultaneous disruption of the three diaphragms and subsequent rapid decompression of the sample. Calculated decompression rates of a $5 \mathrm{~cm}$ long sample, range from 5 to $23 \mathrm{MPa} / \mathrm{ms}$ [1]. The sample fragments if its strength is overcome and the fragments were collected in the LPT section after rinsing with water. This wet collection procedure produces mass yields of more than $97 \%$ of the initial weight. The experimental conditions are reported in Table 1.

\section{Pyroclast analysis}

\subsection{Size distribution, morphology and water content of the fragments}

The recovered pyroclasts were sieved to obtain fragment size distributions (FSD). The automatic sieving was performed with care to prevent secondary breakage of these sometimes highly porous and fragile particles (errors due to loss of particles and breaking are less than 3 and $5 \mathrm{wt} \%$, respectively). We did not sieve particles below $63 \mu \mathrm{m}$ in diameter, referred as an arbitrary $40 \mu \mathrm{m}$ diameter (4.5 $\Phi$ units). The mean and median diameters were calculated after [18].

Pyroclasts of different sizes were selected for the morphological study by scanning electron microscopy (JEOL 840A SEM). The aim was to characterize the fragment shapes and outlines in order to infer aspects of the fragmentation processes they experienced. 
The glass component of the fragments was analyzed for water content by infrared spectroscopy following the procedure used for the starting hydrated glasses. Where the glass areas were too small for infrared spectroscopy measurements, the fragments were crushed below the size of the smallest bubbles for water determination by Karl-Fischer titration. If the amount of fragmented material was too low for Karl-Fischer titration analysis, water contents were calculated after [11].

\subsection{Vesicularity}

Fragments were selected for qualitative and quantitative analyses of the vesicularity. The porosity, bubble shape and bubble size distribution (BSD) were determined by image analysis from SEM pictures of the embedded fragments used for the fragment morphology study. The porosity was determined from the two-dimensional sections and considered equivalent to the volume percent of pores. By repeated measurements, it appeared that the higher the porosity, the larger the errors on the vesicularity (up to \pm 8 at 83 vol\%; Table 1), probably due to pumice damage during polishing. The bubble sizes were defined by their measured diameters. In case of very elongated pores (tubes), the full length of the elongation is not measurable because of intersection by the fragmentation planes, so that pore sizes are defined by the diameter of the section normal to the tube elongation preceded by a ' $T$ ' (for tube).

In each experiment, a minority of the fragments was nearly or fully glassy (i.e. very few bubbles). The vesiculation experiments (without decompression, experiments 1 and 2, Table 1) revealed that these fragments might represent the rims at the contact with the holder. These bubble-depleted parts were not considered in our vesicularity study.

\section{Results}

\subsection{Vesicularity, pore morphology and bubble size distribution the pyroclasts}

Low porous ( $<50$ vol\%) fragments have average vesicularities 5 to 15 vol\% higher than the calculated vesicularities (Fig. 1). Vesicularities measured on highly porous fragments are in better agreement with the calculated ones, although fragments from bubble-bearing starting samples are on average $5 \mathrm{vol} \%$ (up to $10 \mathrm{vol} \%$ ) less porous than the calculated values.

Pores are either isotropic (Fig. 2a,b,d) or elongated (Fig. 2c,e). Fragments less porous than 50 vol\% only display isotropic pores, but above $\sim 50 \mathrm{vol} \%$ porosity, pyroclasts show either tubes or isotropic pores (Table 2). The tubes are always wider than $40 \mu \mathrm{m}$, whereas isotropic pores are smaller than $\sim 50 \mu \mathrm{m}$ in diameter (except in experiment 24 ). Bubble size distributions are either unimodal or bimodal. Bimodal BSDs only characterize highly porous samples $(\alpha>60$ vol\%), whose starting glass cylinders contained bubbles, so that the population of large bubbles (second mode of the BSD) might represent expansion of the pre-existing pores.

\subsection{Morphology and size distribution of the pyroclasts}

Fragments exhibit plate-like shapes (Fig. 2d,e,f) and have angular outlines, irrespective of the pore size or shape.

Under rapid decompression, three samples did not experience fragmentation (experiments 18 , $19,20)$ and two were fragmented in a small number of particles (experiments 11, 27). For the other experiments, FSDs are reported in Table 2. The distribution is always unimodal and the 
particles, ranging from -2.5 to $4.5 \Phi$ units (5.6 to $0.04 \mathrm{~mm}$ ) correspond to coarse ash according to the classical size scale of volcanic clasts. For most of the experiments, the mean diameters are similar to the median diameters or slightly skewed to finer sizes.

\section{Discussion}

\subsection{Pre-fragmentation conditions}

\subsubsection{Foaming}

Our samples were able to foam under decompression as low as $1 \mathrm{MPa}$ (experiment 2), which was only observed in crystal-bearing samples (heterogeneous nucleation, [19]). Therefore, we think that water nucleation in our samples was heterogeneous, probably due to tiny bubbles, microfractures or impurities in the starting glass cylinders.

A vital point in our assumption that no significant viscous strain occurs during or after fragmentation is the question whether or not fragment porosity equals pre-fragmented foam porosity. The water solubilities calculated for the HPT section conditions agree with measured water contents within $0.4 \mathrm{wt} \%$ (Table 1), so that water did not diffuse from the melt to the bubbles during fragmentation. However, calculated cooling times up to $10 \mathrm{~s}$ for a particle radius of $2 \mathrm{~mm}$ (thermal diffusivity of $4 \times 10^{-7} \mathrm{~m}^{2} / \mathrm{s}$ ) are larger than the decompression time $\left(10^{-3} \mathrm{~s}[1]\right)$, so that the gas in the fragments are likely to expand after decompression, especially at melt viscosities below $10^{8} \mathrm{~Pa}$ s for which bubble growth is not impeded. Our experimental pyroclasts are mostly more porous with respect to the calculated vesicularities (except fragments from bubble-bearing starting materials), suggesting that the actual porosity of the pyroclasts might overestimate the porosity prior to fragmentation on average by 5 vol\% and up to 15 vol\% (Table 1).

\subsubsection{Isotropic versus tube pumices}

Either isotropic or tube pumices were generated in the experiments. A crucial point for our study is the determination of the pre-fragmentation pore characteristics, i.e. whether tube pumices were formed before or during fragmentation. Tubes can certainly be formed before decompression, as illustrated by the tubes in experiment 1 where no decompression and fragmentation occurred. In order to determine whether tubes can also occur during decompression, we compared the timescales of fragment cooling and bubble elongation. Bubble elongation is parameterized by the capillary number $(\mathrm{Ca})$, giving the ratio of the viscous forces which act to deform a bubble to the interfacial forces which tend to maintain the sphericity [20]: $\mathrm{Ca}=\dot{\varepsilon} \eta R / \sigma$ ( $\dot{\varepsilon}$ is the strain rate, $\eta$ is the melt viscosity, $R$ is the bubble radius and $\sigma$ is the surface tension). A Ca number of 1 represents the maximum strain rate due to flow around the bubble that may occur without deforming the bubble to a non-spherical shape [21]. For $\mathrm{Ca}=1, \eta=10^{5.7} \mathrm{~Pa} \mathrm{~s}, R=25 \mu \mathrm{m}$ and $\sigma=0.15 \mathrm{~N} \mathrm{~m}^{-1}$ [22], $\varepsilon^{\prime}$ is of the order of $10^{-2} \mathrm{~s}^{-1}$, giving a time scale of $100 \mathrm{~s}$ (up to $10^{4} \mathrm{~s}$ for $\eta=10^{8.1} \mathrm{~Pa} \mathrm{~s}$ ). The slowest cooling time of $\sim 10 \mathrm{~s}$ (see above) is shorter than the bubble elongation timescale, so that bubbles are very unlikely to elongate during or after decompression.

The reason why either isotropic or tube pores are generated is not yet elucidated. However, it seems to be related to bubble size. Indeed, isotropic pumices were generated when bubbles did not grow above $\sim 50 \mu \mathrm{m}$ in diameter (even at total porosities higher than $70 \mathrm{vol} \%$ ), but once they grew up to $\sim 50 \mu \mathrm{m}$ at a total porosity larger than $\sim 50 \mathrm{vol} \%$, pores end up as tubes 
(except for experiment 24). It seems that $\sim 50$ vol\% of porosity is the maximal volume for packing spheres of $\sim 50 \mu \mathrm{m}$ in our experimental configuration where the sample holder closely surrounds the samples, thus restricting lateral bubble expansion.

\subsection{Fragmentation conditions}

\subsubsection{Fragmentation mechanism}

From the plate-like shape fragments they recovered from experiments carried out using Mount St. Helens dacite and from observation through high-speed cameras [23], Alidibirov and Dingwell [24] concluded that the main fracturing process occurring in the fragmentation bomb apparatus is a spallation fragmentation. The spallation fragmentation wave refers to the decompression of magma containing pressurized gas vesicles (either close or open porosity). Fragmentation is initiated by the disruption of the interbubble partitions due to the pressure differential between gas in pores and ambient pressure, and propagates downwards into the next layer of pores. Our plate-like shape pyroclasts are very likely to have experienced the same layer-by-layer fragmentation process.

Three size distributions are commonly proposed to account for fragment populations generated in industrial and natural processes: log-normal, power-law and exponential [25]. Fragmentation of a solid by an explosion or with a hammer generates a power-law distribution (log-normal distributions rather describe droplets produced by the breakup of a liquid jet and the exponential distributions characterize sequential processes such as grinding and milling). The inset of Fig. 3 shows that the fragment sizes plotted in the power-law typical coordinates give almost straight lines, suggesting that the FSDs produced by a spallation fragmentation are close to follow a power-law, with exponents $D$ ranging from 2.0 to 4.1 (Table 2).

\subsubsection{Brittle versus ductile fragmentation}

Recently, brittle versus ductile fragmentation of the magma has been discussed [2]. If the applied stress is sufficient to push the strain response of the magma into the glass transition region and overcome its strength, the magma fragments brittle. The following observations of the fragment outlines and calculations allow us to resolve whether a brittle or ductile fragmentation occurred. The tube pumices have outlines sharply cutting the tubes (e.g. Fig. 2c). By a ductile fragmentation, these tubes would have been distorted, tapered or necked at their tips. The brittle fragmentation is confirmed by the process timescales. When the application time of the stress is shorter than the relaxation time required for the melt to deform in a viscous manner, brittle fragmentation can occur. The relaxation time $\left(\tau_{\mathrm{s}}\right)$ of a product in response to an applied stress is given by the Maxwell relation: $\tau_{\mathrm{s}}=\eta / G$, where $\eta$ is the viscosity and $G$ the elastic modulus which is proportional to Young's modulus for tensile stresses. For a Young's modulus of $10^{10} \mathrm{~Pa}$, corresponding to a dacitic glassy matrix [26] and bubbly-melt viscosities between $10^{7}$ to $10^{9.4} \mathrm{~Pa} \mathrm{~s}$ (Table 1 ), $\tau_{\mathrm{s}}$ ranges from $10^{-3}$ to $10^{-1} \mathrm{~s}$, respectively. The decompression time $\Delta t_{\mathrm{dec}}\left(\sim 10^{-3} \mathrm{~s}\right)$ is shorter than $\tau_{\mathrm{s}}$, thus suggesting a brittle fragmentation. An exception is experiment 10, having a relaxation time $\tau_{\mathrm{s}}$ of $\sim 10^{-3.5} \mathrm{~s}$, thus permitting a short viscous deformation during fragmentation.

The decompression threshold at which fragmentation occurs gives the strength of the material. No fragmentation occurred in experiment 20 under rapid decompression at $5 \mathrm{MPa}$ (porosity of 58 vol\%, melt viscosity of $10^{7.9} \mathrm{~Pa} \mathrm{~s}$ ). The sample from experiment 11 was however slightly 
fragmented at $5 \mathrm{MPa}$ (porosity of 45 vol\%, melt viscosity of $10^{7.2} \mathrm{~Pa} \mathrm{~s}$ ). This suggests a strength for our samples of $\sim 5 \mathrm{MPa}$.

\subsubsection{Parameters controlling the fragment size}

We investigated the effects of the porosity and pressure on the power-law exponent $D$ (Fig. 3 ). Samples less porous than $50 \mathrm{vol} \%$ are characterized by $D<3.0$, reflecting that the FSDs are controlled by the large fragments. Above $50 \mathrm{vol} \%$ of porosity, FSDs are characterized either by $D<3.0$ when samples were fragmented below $15 \mathrm{MPa}$ or by $D>3.0$ when fragmented from $15 \mathrm{MPa}$ (except experiments 9 and 22). This suggests that dense material (porosity $<50 \mathrm{vol} \%$ ) does not fragment finely under rapid decompression up to $15 \mathrm{MPa}$. Vesicular material (porosity $>50 \mathrm{vol} \%$ ) only fragments into fine particles at high decompressions (>15 MPa). Kaminski and Jaupart [27] used $D<3.0$ to argue for primary fragmentation (a single event) and $D>3.0$ for secondary fragmentation (such as repeat fragment collisions). They performed experiments by hitting pumices with a hammer, where the size and the number of the fragments produced depend on the energy input (at small energy input, only small pieces at the surface of the sample can be broken). In contrary, the spallation fragmentation always concerns the whole sample, as the over-pressurized layer of bubbles bursting into the free surface exposes the next layer to fragmentation. Two hypotheses can be proposed for $D>3.0$ in our experiments, depending on how the physic of the fragmentation mechanisms compares with the experiments of [27]: primary break-up in a context of spallation fragmentation if the processes do not compare or secondary fragmentation of highly vesiculated melts $(<50 \mathrm{vol} \%)$ decompressed from $15 \mathrm{MPa}$ (evidence for secondary fragmentation is however not supported by any peculiarities of the fragment shape or texture).

The pressure effect on the FSDs of vesicular samples (porosity $>50$ vol\%) was further investigated by comparing experiments where starting material have comparable prefragmentation physical properties. Fig. 4a shows that the higher the decompression, the finer the particles. The correlation between pressure and fragment size suggests a fragment size decrease of 0.2 $\Phi$ unit/MPa. Higher decompressions indeed involve larger released energy applying on any flaws and heterogeneities of the sample through which failure will be initiated. Fig. $4 \mathrm{~b}$ shows the effect of the pore shape on the FSDs, suggesting that tube pumices are generally more finely fragmented than samples with isotropic pores. This could reflect the low strength of a material containing tube pores due to thin walls in between the tubes. The effect of the melt viscosity on FSD is not straightforward and would require further systematic investigations to be determined.

\subsubsection{Applicability to dome explosions}

Our experimental device generating fragmentation by rapid decompression best simulates dome explosions, consequently to a destabilization (e.g. landslide) whereby the underlying pressurized magma is suddenly exposed to much lower pressures. Melnik and Sparks [28] have recently theoretically demonstrated that ground deformation patterns or vulcanian eruptions observed in Soufriere Hills dome (Montserrat) [29] could be attributed to pressurization at shallow levels (upper part of the conduit) rather than in the deep magma chamber. Our experiments are consistent with this model, by showing that small overpressures (less than $20 \mathrm{MPa}$ ) can lead to magma fragmentation when rapidly decompressed. In addition, we suggest that the magnitude of the decompression is a parameter much more efficient in dome explosions than melt porosity, bubble shape or melt viscosity of the pre-fragmented magma. However, our starting samples are crystal-free, thus having 
physical properties, which do not match those of magmas in common domes. Experimental investigation using crystal-bearing samples is in progress.

Table 1. Experimental conditions

Expt. No. Starting glass cylinders Nucleation conditions Fragment characteristics

\begin{tabular}{|c|c|c|c|c|c|c|c|c|c|c|c|c|}
\hline & $\begin{array}{l}\underline{\mathrm{a}} \\
(\mathrm{wt} \%)\end{array}$ & $\begin{array}{l}\operatorname{Pini}^{\mathrm{b}} \\
(\mathrm{MPa})\end{array}$ & $\begin{array}{l}\text { Weight } \\
(\mathrm{g})\end{array}$ & $\begin{array}{l}T \\
\left({ }^{\circ} \mathrm{C}\right)\end{array}$ & $\begin{array}{l}P^{\mathrm{c}} \\
(\mathrm{MPa})\end{array}$ & $\begin{array}{l}t \\
(\min )\end{array}$ & $\begin{array}{l}\mathrm{Cw}_{\text {calc }}{ }^{-\mathrm{d}} \\
(\mathrm{wt} \%)\end{array}$ & $\begin{array}{l}\mathrm{Cw}_{\mathrm{fin}}{ }^{\mathrm{e}} \\
(\mathrm{wt} \%)\end{array}$ & $\begin{array}{l}\alpha_{\text {calc }}{ }^{\mathrm{f}} \\
(\mathrm{vol} \%)\end{array}$ & $\begin{array}{l}\alpha_{\text {meas }} \\
(\operatorname{vol} \%)\end{array}$ & $\begin{array}{l}\log \eta_{\text {ini }}-\log \eta_{\text {fin }}{ }^{\mathrm{g}} \\
(\mathrm{Pa} \mathrm{s})\end{array}$ & $\begin{array}{l}\log \eta_{\alpha} \underline{\underline{h}} \\
(\mathrm{~Pa} \mathrm{~s})\end{array}$ \\
\hline 27 & $0^{\circ}$ & 0.1 & 6.166 & 900 & 10 & 1 & 0.0 & $0.00 \mathrm{I}$ & 0 & $4 \pm 1$ & $12.4-12.4$ & - \\
\hline 18 & $1.4-1.4$ & 11 & $0.110_{-}^{*}$ & 800 & $4(6.3)$ & 30 & 0.9 & - & $58 \pm 2$ & $64 \pm 5$ & $6.9-7.5$ & 8.6 \\
\hline 5 & $1.4-1.4$ & 11 & $0.717_{-}^{\circ}$ & 800 & $4.5(6.5)$ & 30 & 1.0 & $1.0 \mathrm{I}$ & $49 \pm 2$ & $61 \pm 5$ & $6.9-7.4$ & 8.4 \\
\hline 8 & $1.4-1.4_{-}^{\circ}$ & 11 & 7.560 & 900 & $5(7.3)$ & 30 & 1.0 & $0.7 \mathrm{~K}$ & $63 \pm 2$ & $61 \pm 5$ & $5.8-6.7$ & 7.7 \\
\hline 20 & $1.5-1.6$ & 14 & $1.128_{-}^{\circ}$ & 760 & $5(6.4)$ & 30 & 1.0 & - & $52 \pm 3$ & $58 \pm 5$ & $7.2-7.9$ & 8.8 \\
\hline 11 & $1.6-1.7^{\circ}$ & 16 & $2.459_{-}^{\circ}$ & 784 & $5(7.6)$ & 30 & 1.0 & $1.3 \mathrm{~K}$ & $44 \pm 3$ & $45 \pm 3$ & $6.8-7.2$ & 7.9 \\
\hline 10 & $1.7-1.8$ & 18 & $2.571_{-}^{\circ}$ & 900 & $10(\sim 12)$ & 30 & 1.4 & - & $32 \pm 3$ & $42 \pm 3$ & $5.5-5.8$ & 6.5 \\
\hline 2 & $1.4-1.4$ & 11 & $0.193_{-}^{\circ}$ & 900 & 10 & 60 & 1.4 & $1.2 \mathrm{I}$ & $19 \pm 2$ & $23 \pm 3$ & $5.8-6.0$ & - \\
\hline 28 & $1.5-1.5_{-}^{\circ}$ & 13 & 7.367 & $\sim 360$ & 10 & 1 & 1.5 & - & 0 & $<1$ & $12.4-12.4$ & 12.4 \\
\hline 16 & $2.6-2.6$ & 42 & 7.335 & 750 & $5(8.8)$ & 30 & 1.0 & $1.0 \mathrm{~K}$ & $77 \pm 2$ & $74 \pm 8$ & $6.5-8.1$ & 9.4 \\
\hline 13 & $2.4-2.4_{-}^{\circ}$ & 36 & $0.850_{-}^{\circ}$ & 750 & $5(8.2)$ & 30 & 1.0 & $1.0 \mathrm{~K}$ & $75 \pm 2$ & $71 \pm 8$ & $6.6-8.1$ & 9.3 \\
\hline 7 & $2.0-2.2$ & 26 & 7.692 & 800 & $10(11.1)$ & 25 & 1.4 & $1.3 \mathrm{~K}$ & $46 \pm 4$ & $62 \pm 5$ & $6.3-7.0$ & 8.0 \\
\hline 17 & $2.1-2.4$ & 31 & $1.335_{-}^{\circ}$ & 750 & $10(11.1)$ & 30 & 1.5 & $1.8 \mathrm{~K}$ & $32 \pm 5$ & $43 \pm 3$ & $6.7-7.1$ & 7.7 \\
\hline 25 & $2.5_{-}^{\circ}$ & 38 & 7.309 & 630 & 15 & 1 & 2.5 & $2.4 \mathrm{I}$ & $5 \pm 1$ & $12 \pm 3$ & $8.2-8.3$ & 8.3 \\
\hline 9 & $3.2-3.2^{\circ}$ & 66 & 7.750 & 900 & $10(12)$ & 30 & 1.4 & $1.4 \mathrm{~K}$ & $68 \pm 2$ & $72 \pm 8$ & $4.7-5.8$ & 7.1 \\
\hline 29 & $3.3-3.4_{-}^{\circ}$ & 75 & $1.183_{-}^{\circ}$ & 800 & 10 & 25 & 1.4 & $1.5 \mathrm{I}$ & $67 \pm 3$ & $62 \pm 5$ & $5.5-6.8$ & 7.8 \\
\hline 22 & $3.7-3.9^{\circ}$ & 97 & 7.178 & 750 & $10(11.2)$ & 30 & 1.4 & $1.2 \mathrm{~K}$ & $73 \pm 4$ & $62 \pm 5$ & $5.8-7.8$ & 8.8 \\
\hline 24 & $3.9-3.9^{\circ}$ & 102 & 6.092 & 900 & $15(17.3)$ & 30 & 1.6 & $1.2 \mathrm{~K}$ & $68 \pm 2$ & $70 \pm 8$ & $4.4-6.0$ & 7.3 \\
\hline 14 & $3.9-3.9^{\circ}$ & 102 & 7.508 & 822 & 18 & 1 & 1.8 & $1.4 \mathrm{~K}$ & $60 \pm 2$ & $61 \pm 5$ & $5.0-6.6$ & 7.6 \\
\hline 19 & $4.4-4.6$ & 143 & $0.154_{-}^{\circ}$ & 800 & $4(6.6)$ & 30 & 0.9 & - & $91 \pm 4$ & - & $5.0-7.5$ & - \\
\hline 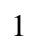 & $4.4-4.6$ & 143 & $0.090_{-}^{\circ}$ & 900 & 10 & 60 & 1.4 & $1.2 \mathrm{~K}$ & $80 \pm 4$ & $83 \pm 8$ & $4.2-6.0$ & - \\
\hline 0 & $4.4-4.6$ & 143 & $0.885_{-}^{\circ}$ & 755 & $15(15.3)$ & 5 & 1.8 & $1.8 \mathrm{~K}$ & $65 \pm 4$ & $52 \pm 5$ & $5.4-7.0$ & 7.8 \\
\hline 23 & $4.3-4.7^{\circ}$ & 140 & 7.622 & 750 & 15 & 30 & 1.8 & $1.5 \mathrm{~K}$ & $68 \pm 6$ & $61 \pm 5$ & $5.5-7.4$ & 8.4 \\
\hline 21 & $5.6-5.8$ & 234 & $1.312_{-}^{\circ}$ & 900 & $15(15.3)$ & 30 & 16 & $1.6 \mathrm{~K}$ & $80 \pm 4$ & $83 \pm 8$ & $3.8-5.7$ & 9.1 \\
\hline
\end{tabular}

A : Water content at each end of the starting glass cylinder measured by infrared spectroscopy, except for experiments 9 and 10, for which the second value was obtained by Karl-Fischer titration. Analytical errors of $\sim 0.2$ wt $\%$.

\footnotetext{
$\circ$ : Starting glasses with bubbles ( $<3$ vol\%, diameter of $\sim 50 \mu \mathrm{m}$ ), except for experiments 23 (diameter up to 150 $\mu \mathrm{m})$ and $24(11 \mathrm{vol} \%$, diameter up to $150 \mu \mathrm{m})$.

B : Solubility pressure calculated after $[11]$ corresponding to $\mathrm{Cw}_{\text {ini. }}$ Pini-P gives the supersaturation pressure for vesiculation.

*: or $8 \mathrm{~mm}$ diameter samples.

$\mathrm{C}$ : Pressure of the HPT section. Number in bracket gives bursting pressure for the single diaphragm experiment (see text for details).

D : At $P$, after [11].

E : Glass water content of the fragments measured by Karl-Fischer titration (K) or infrared spectroscopy (I).

F : Vesicularity $(\alpha)$ calculated after [12]: $\alpha=\left(1+\rho_{\mathrm{w}} /\left(\left(\mathrm{Cw}_{\text {ini }}-\mathrm{Cw}_{\text {fin }}\right) \rho_{\mathrm{m}}\right)\right)^{-1}$, where $\rho_{\mathrm{w}}$ is the water density [13], $\rho_{\mathrm{m}}$ the melt density of the starting hydrated HPG8 glasses (bubble-free) by the double-weight method in air and ethanol (Mettler Toledo AG204). As this yields a glass density $\left(\sim 2.338 \mathrm{~g} / \mathrm{cm}^{3}\right.$ for $\left.1 \mathrm{wt} \% \mathrm{H}_{2} \mathrm{O}\right)$, we subtracted the density difference (i.e. $0.032 \mathrm{~g} / \mathrm{cm}^{3}$ ) obtained by $[14]$ between $\mathrm{HPG} 8$ glass at $20^{\circ} \mathrm{C}$ and melt at $900^{\circ} \mathrm{C}$.

$\mathrm{G}$ : Melt viscosity calculated after [15] for average $\mathrm{Cw}_{\text {ini }}$ and $\mathrm{Cw}_{\text {fin }}$ at $T$.

$\mathrm{H}$ : Bubbly-melt viscosity calculated after [16], for highly concentrated suspensions ( $\mathrm{Phi}_{\max }=85$ ), considering a rigid behavior of the pores under the $10^{-3} \mathrm{~s}$ decompression time.
} 


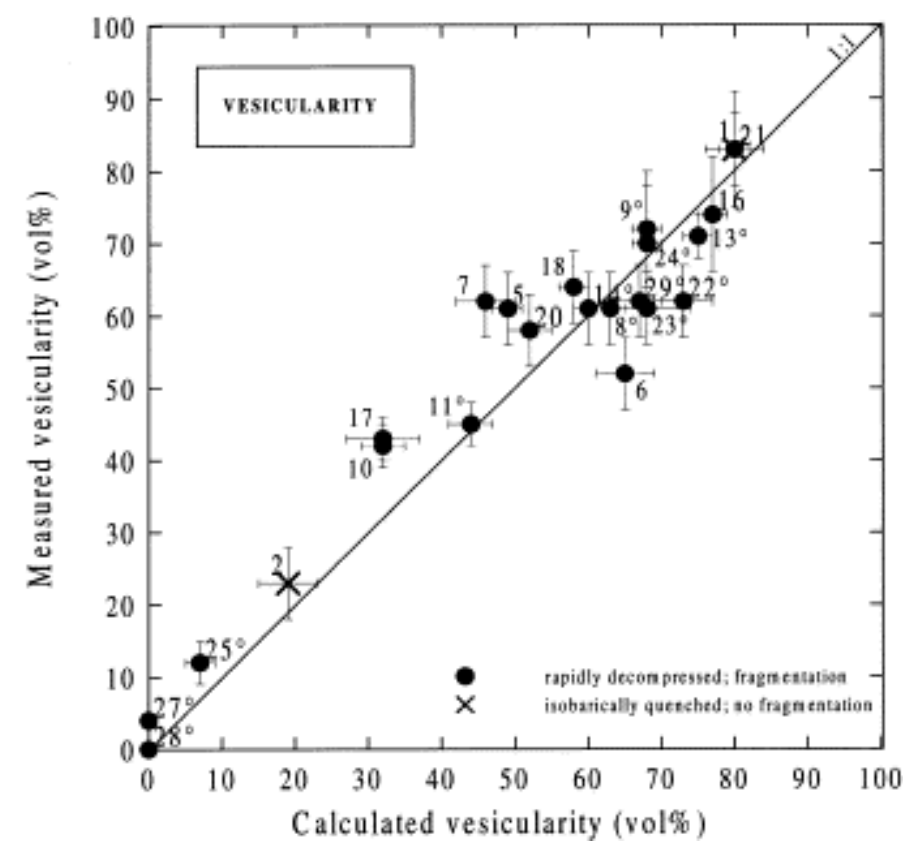

Fig. 1. Measured versus calculated vesicularity. Labels represent the experiment number $\left({ }^{\circ}\right.$ for bubblebearing starting samples as reported in Table 1). Error bars on measured vesicularities are determined from repeated measurements by image analysis. Error bars on the calculated vesicularities are \pm 2 vol\% plus the water content difference between both ends of the starting glass cylinders (see Table 1). 


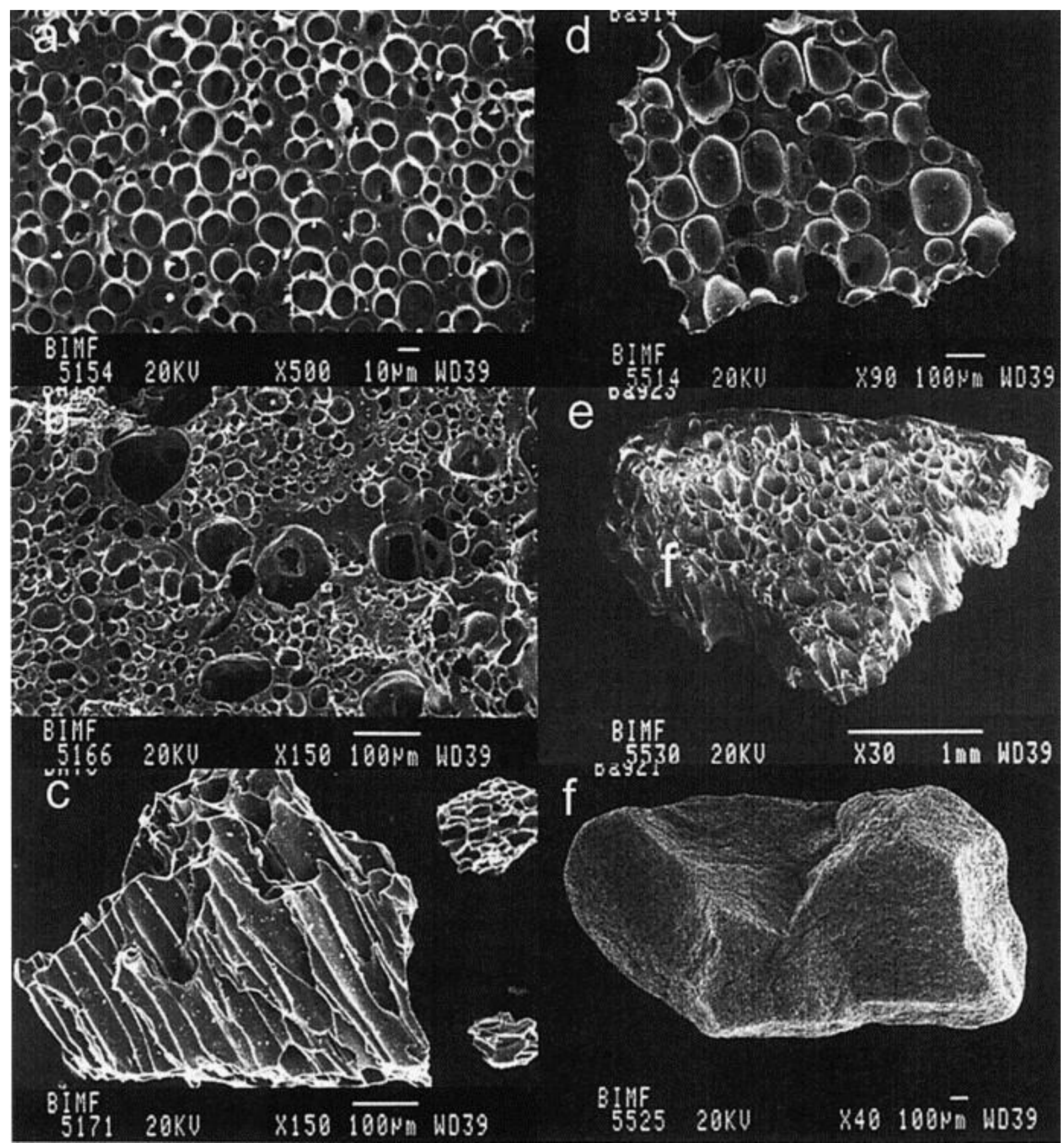

Fig. 2. SEM images showing the pore and fragment morphologies. (a) Experiment 10, (b) experiment 8 , (c) experiment 6, (d) experiment 14, (e) experiment 23 and (f) experiment 21. 
Table 2. Size distributions of bubbles and fragments

\begin{tabular}{|c|c|c|c|c|c|c|c|c|c|c|c|}
\hline \multirow[t]{2}{*}{$\begin{array}{l}\text { Expt } \\
\text {. No. }\end{array}$} & \multirow{2}{*}{$\begin{array}{l}P \\
{ }^{(\mathrm{MPa}}\end{array}$} & \multirow{2}{*}{$\begin{array}{l}\text { Fragmen } \\
\text { t weight } \\
\text { (g) }\end{array}$} & \multirow{2}{*}{$\begin{array}{l}\text { Porosity } \\
, \alpha \\
\text { (vol\%) }\end{array}$} & \multicolumn{4}{|c|}{$\begin{array}{l}\text { Bubble size distribution } \\
\text { (diameter in } \mu \mathrm{m} \text { ) }\end{array}$} & \multicolumn{4}{|c|}{$\begin{array}{l}\text { Fragment size distribution ( } \Phi \\
\left.\text { unit }=-\log _{2} \mathrm{~d} \text { in } \mathrm{mm}\right)\end{array}$} \\
\hline & & & & $\begin{array}{l}\text { Main } \\
\text { mode } \\
\text { (averag } \\
\text { e } \\
\text { bubble } \\
\text { size) }\end{array}$ & $\begin{array}{l}\text { Second } \\
\text { mode }\end{array}$ & $\begin{array}{l}\text { Total } \\
\text { rang } \\
\mathrm{e}\end{array}$ & $\begin{array}{l}\text { Averag } \\
\text { e } \\
\text { bubble } \\
\text { size } \\
\text { label }^{\underline{a}}\end{array}$ & $\begin{array}{l}\text { Total } \\
\text { range }\end{array}$ & $\begin{array}{l}\text { Mean } \\
\text { diamete } \\
r\end{array}$ & $\begin{array}{l}\text { Median } \\
\text { diamete } \\
r\end{array}$ & $D^{\mathrm{b}}$ \\
\hline $27^{\circ}$ & 10 & - & $4 \pm 1$ & $7 \pm 1$ & - & $0-25$ & 10 & - & - & - & - \\
\hline 18 & 4 & - & $64 \pm 5$ & $40 \pm 10$ & - & $\begin{array}{l}11- \\
102\end{array}$ & 50 & - & - & - & - \\
\hline 5 & 4.5 & 0.129 & $61 \pm 5$ & $\sim 50$ & - & $\begin{array}{l}5- \\
100\end{array}$ & T50 & $\begin{array}{l}-1.0 / 4 \\
0\end{array}$ & 0.46 & 0.26 & $\begin{array}{l}2 . \\
3\end{array}$ \\
\hline $8^{\circ}$ & 5 & 7.146 & $61 \pm 1$ & $40 \pm 10$ & $\sim 100$ & $\begin{array}{l}35- \\
442\end{array}$ & 50 & $\begin{array}{l}-2.5 / 4 . \\
5\end{array}$ & 0.32 & 0.27 & $\begin{array}{l}2 . \\
1\end{array}$ \\
\hline 20 & 5 & - & $58 \pm 5$ & $2 \pm 1$ & - & $1-6$ & 10 & - & - & - & - \\
\hline $11^{\circ}$ & 5 & - & $45 \pm 3$ & $2.5 \pm 0.5$ & - & $1-11$ & 10 & - & - & - & - \\
\hline 10 & 10 & - & $42 \pm 3$ & $10 \pm 4$ & - & $4-32$ & 10 & - & - & - & - \\
\hline 2 & 10 & - & $23 \pm 3$ & $38 \pm 3$ & - & $\begin{array}{l}33- \\
71\end{array}$ & 50 & - & - & - & - \\
\hline $28^{\circ}$ & 10 & 7.097 & $<1$ & $33 \pm 3$ & - & $0-90$ & 50 & $\begin{array}{l}-2.5 / 4 \\
5\end{array}$ & -0.37 & -0.41 & $\begin{array}{l}2 . \\
1\end{array}$ \\
\hline 16 & 5 & 5.252 & $74 \pm 8$ & $90 \pm 40$ & $\begin{array}{l}275 \pm 2 \\
5\end{array}$ & $\begin{array}{l}33- \\
719\end{array}$ & T100 & $\begin{array}{l}-2.0 / 4 \\
5\end{array}$ & 1.22 & 1.05 & $\begin{array}{l}2 . \\
8\end{array}$ \\
\hline $13^{\circ}$ & 5 & 0.179 & $71+8$ & $\sim 10$ & - & $1-50$ & 10 & $\begin{array}{l}-1.5 / 4 \\
0\end{array}$ & -0.68 & -0.57 & $\begin{array}{l}2 . \\
2\end{array}$ \\
\hline 7 & 10 & 4.958 & $62 \pm 15$ & - & $\begin{array}{l}33- \\
274\end{array}$ & T50 & $\begin{array}{l}-2.0 / 4 \\
5\end{array}$ & 1.39 & 1.29 & 2.7 & \\
\hline 17 & 10 & 1.159 & $43 \pm 3$ & $5 \pm 1$ & - & $\begin{array}{l}1.4- \\
9\end{array}$ & 10 & $\begin{array}{l}-1.5 / 4 \\
0\end{array}$ & 0.86 & 0.77 & $\begin{array}{l}2 . \\
1\end{array}$ \\
\hline $25^{\circ}$ & 15 & 6.836 & $12 \pm 3$ & $40 \pm 10$ & - & $\begin{array}{l}34- \\
206\end{array}$ & 50 & $\begin{array}{l}-2.5 / 4 \\
5\end{array}$ & -0.58 & -0.66 & $\begin{array}{l}2 . \\
0\end{array}$ \\
\hline $9^{\circ}$ & 10 & 5.546 & $72 \pm 8$ & $200 \pm 80$ & - & $\begin{array}{l}35- \\
442\end{array}$ & T100 & $\begin{array}{l}-1.0 / 4 \\
5\end{array}$ & 2.00 & 1.96 & $\begin{array}{l}3 . \\
3\end{array}$ \\
\hline $29^{\circ}$ & 10 & 0.073 & $62 \pm 5$ & $50 \pm 20$ & $\begin{array}{l}175 \pm 2 \\
5\end{array}$ & $\begin{array}{l}32- \\
728\end{array}$ & 50 & $\begin{array}{l}-0.5 / 4 \\
0\end{array}$ & 1.22 & 1.05 & $\begin{array}{l}2 . \\
5\end{array}$ \\
\hline $22^{\circ}$ & 10 & 5.234 & $62 \pm 5$ & $70 \pm 10$ & $30 \pm 10$ & $\begin{array}{l}15- \\
177\end{array}$ & T50 & $\begin{array}{l}-1.0 / 4 \\
5\end{array}$ & 2.10 & 2.07 & $\begin{array}{l}3 . \\
3\end{array}$ \\
\hline $24^{\circ}$ & 15 & 4.793 & $70 \pm 8$ & $125 \pm 25$ & $\begin{array}{l}270 \pm 2 \\
5\end{array}$ & $\begin{array}{l}27- \\
468\end{array}$ & 100 & $\begin{array}{l}-0.5 / 4 \\
5\end{array}$ & 2.26 & 2.26 & $\begin{array}{l}3 . \\
9\end{array}$ \\
\hline $14^{\circ}$ & 18 & 6.036 & $61 \pm 5$ & $50 \pm 10$ & $110 \pm 5$ & $\begin{array}{l}23- \\
194\end{array}$ & T50 & $\begin{array}{l}-0.5 / 4 . \\
5\end{array}$ & 2.41 & 2.37 & $\begin{array}{l}4 . \\
1\end{array}$ \\
\hline 19 & 4 & - & - & - & - & - & - & - & - & - & - \\
\hline 1 & 10 & - & $83 \pm 8$ & $100 \pm 20$ & $\begin{array}{l}215 \pm 1 \\
5\end{array}$ & $\begin{array}{l}33- \\
270\end{array}$ & T100 & - & - & - & - \\
\hline 6 & 15 & 0.290 & $52 \pm 5$ & $\sim 40$ & - & $\begin{array}{l}10- \\
100\end{array}$ & T50 & $\begin{array}{l}-0.5 / 4 \text {. } \\
5\end{array}$ & 2.16 & 2.21 & $\begin{array}{l}3 . \\
5\end{array}$ \\
\hline
\end{tabular}




\begin{tabular}{|c|c|c|c|c|c|c|c|c|c|}
\hline $23^{\circ}$ & 15 & 5.576 & $61 \pm 5$ & $70 \pm 10$ & $\sim 250$ & $\begin{array}{ll}23- & \text { T50 } \\
348\end{array}$ & $\begin{array}{l}-1.0 / 4 . \\
5\end{array}$ & 2.09 & 2.06 \\
\hline 21 & 15 & 0.497 & $83 \pm 8$ & $2.5 \pm 1$ & $\begin{array}{l}9.5 \pm 0 . \\
5\end{array}$ & $1-11 \quad 10$ & $\begin{array}{l}-1.5 / 4 . \\
5\end{array}$ & 1.70 & 1.65 \\
\hline
\end{tabular}

${ }^{\circ}$ For bubble-bearing starting material.

a

10 for average bubble size (aBS) between 1 and $25 \mu \mathrm{m}, 50$ for aBS between $25,75 \mu \mathrm{m}$ and 100 for aBS above $75 \mu \mathrm{m}$ and $\mathrm{T}$ for tubes.

b

Power-law exponent.

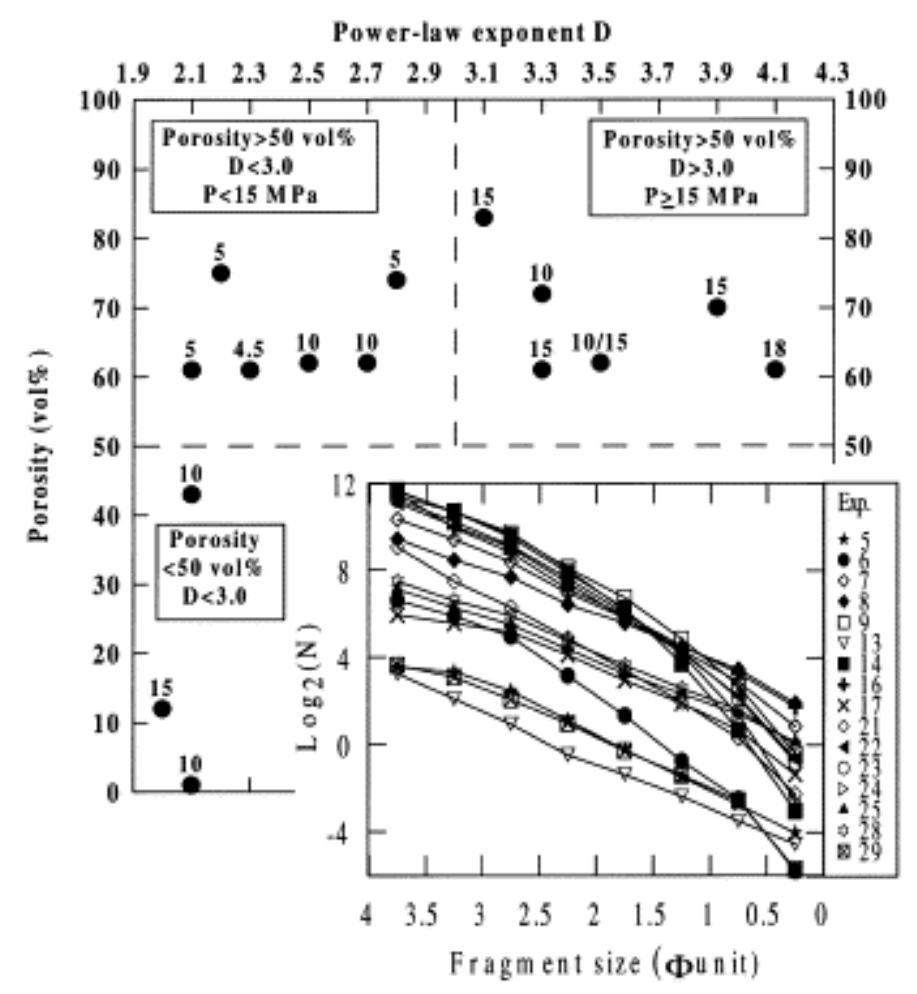

Fig. 3. Parameters controlling the FSD: porosity and pressure effects on the power-law exponent $D$ determined by the slopes of the best fit of the data in the inset. This diagram compares the fragment size distributions with the power-law distribution given by $\log _{2}(N)=r^{-D}$, where $N$ is the number of fragments with radii larger than $r$. The fragment number was determined by dividing the total fragment mass in each sieve (only the 0-4 $\Phi$ unit range is shown, where all experiments can be compared) by the mass of a single fragment (volume of a sphere corresponding to the sieve mesh time the glass density corrected by the porosity $\alpha$ given in Table 1 ). 


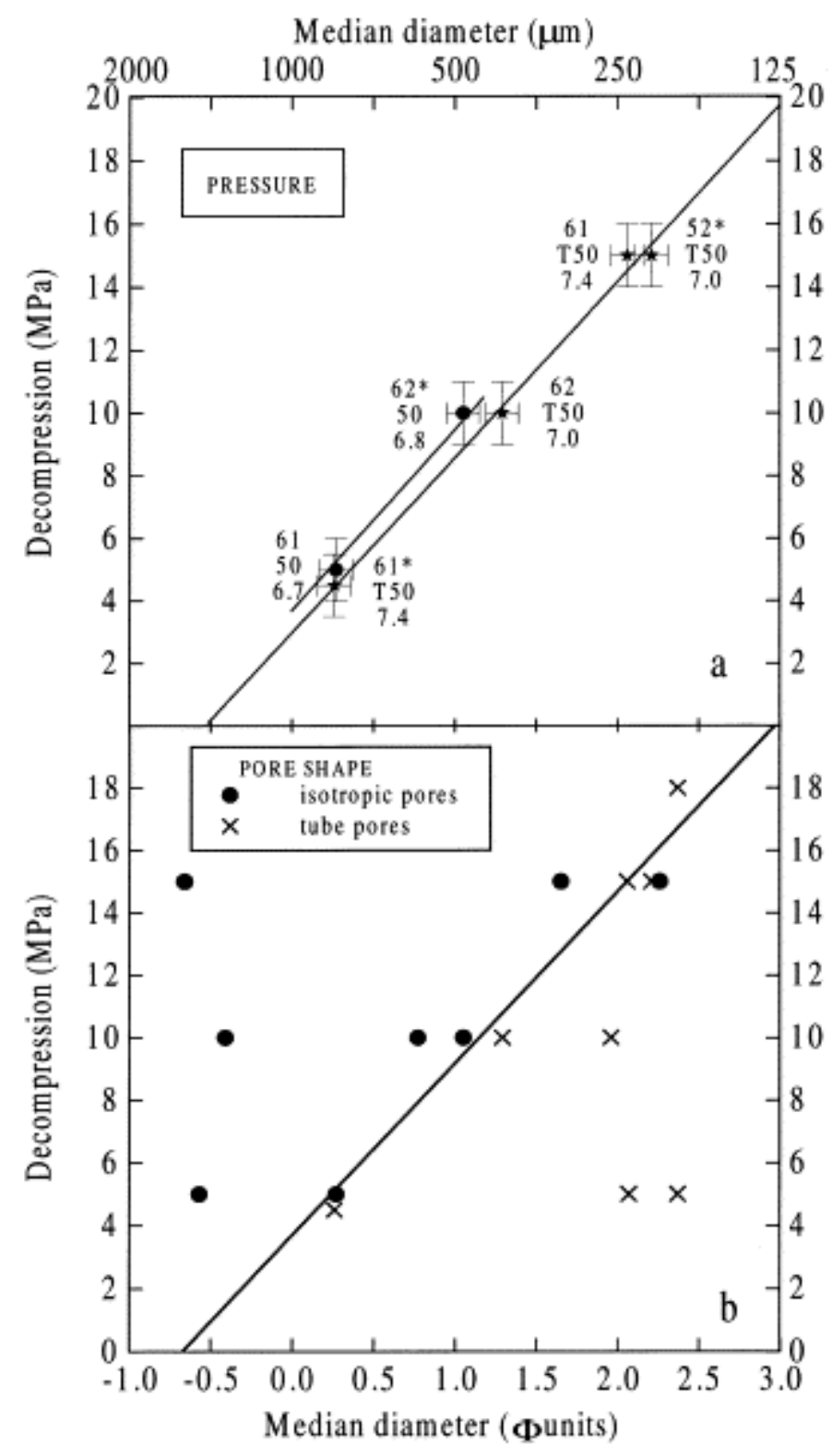

Fig. 4. Parameters controlling the FSD. Median diameter in $\Phi$ unit $=-\log _{2} d$, where $d$ is the diameter in $\mathrm{mm}$ (error of $\pm 0.1 \Phi$ unit). (a) Decompression effect. Labels represent the vesicularity in vol\% (* for 8 $\mathrm{mm}$ in diameter starting glass cylinders), the average bubble size in $\mu \mathrm{m}$ ( $\mathrm{T}$ for tubes) and the logarithm of the melt viscosity (see Table 1 and Table 2). Error of $\pm 2 \mathrm{MPa}$ correspond to a scatter in the porosity of $\pm 5 \mathrm{vol} \%$. The slopes gives a fragment size decrease of $0.2 \Phi / \mathrm{MPa}$. (b) Effect of the pore shape. The line represents the decompression effect of FSD as given in (a).

\section{Acknowledgements}

This work was supported by the EC-TMR-network (FMRX-CT96-0063) on 'hydrous silicate melts' and by the EC (ENV4-CT98-0703) on 'The Physics of Explosive Volcanism', as well as DFG grants to D.B.D. We thank B.C. Schmidt for discussion. We are grateful to G.

Hermannsdörfer for technical assistance, O. Leitner for careful sample preparation and C. Drummer for assistance with the SEM study. We acknowledge R.S.J. Sparks and O. Navon for helpful reviews. [FA] 


\section{References}

D.B. Dingwell, Magma degassing and fragmentation: recent experimental advances, in: A. Freundt, M. Rosi (Eds.), From Magma to Tephra; Modeling Physical Processes of Explosive Volcanic Eruptions, 1998, pp. 1-23.

D.B. Dingwell, Recent experimental progress in the physical description of silicic magma relevant to explosive volcanism, in: J.S. Gilbert, R.S.J. Sparks (Eds.), The Physics of Explosive Volcanic Eruptions, Geol. Soc. London Spec. Publ. 145, 1998, pp. 9-26.

H.M Mader, J.C Phillips, R.S.J Sparks, B Sturtevant

Dynamics of explosive degassing of magma: observations of fragmenting twophase flows

J. Geophys. Res., 101 (1996), pp. 5547-5560

M Alidibirov

A model for viscous magma fragmentation during volcanic blasts

Bull. Volcanol., 56 (1994), pp. 459-465

P Papale

Strain-induced magma fragmentation in explosive eruptions

Nature, 397 (1999), pp. 425-42

H.M Mader, Y Zhang, J.C Phillips, R.S.J Sparks, B Sturtevant, E Stolper

Experimental simulations of explosive degassing of magma

Nature, 372 (1994), pp. 85-88

R.S.J. Sparks, J. Barclay, C. Jaupart, H.M. Mader, J.C. Phillips, Physical aspects of magmatic degassing I. Experimental and theoretical constraints on vesiculation, in: M.R. Carroll, J.R. Holloway (Eds.), Volatiles in Magmas, Reviews in Mineralogy 30, Mineral. Soc. Am., 1994, pp. 413-445.

Y Zhang, B Sturtevant, E.M Stolper

Dynamics of gas-driven eruptions: experimental simulations using $\mathrm{CO}_{2}-\mathrm{H}_{2} \mathrm{O}-$ polymer system

J. Geophys. Res., 102 (1997), pp. 3077-3096

M Alidibirov, D.B Dingwell

Magma fragmentation by rapid decompression

Nature, 380 (1996), pp. 146-148

M Alidibirov, D.B Dingwell

An experimental facility for the investigation of magma fragmentation by rapid decompression

Bull. Volcanol., 58 (1996), pp. 411-416

C.W. Burnham, Development of the Burnham model for prediction of $\mathrm{H}_{2} \mathrm{O}$ solubility in magmas, in: M.R. Carroll, J.R. Holloway (Eds.), Volatiles in Magmas, Reviews in Mineralogy 30, Mineral. Soc. Am., 1994, pp. 123-129. 
C. Jaupart, S. Tait, Dynamics of eruptive phenomena, in: J. Nicholls, J.K. Russell (Eds.), Modern Methods of Igneous petrology: Understanding Magmatic Processes, Reviews in Mineralogy 24, Mineral. Soc. Am., 1989, pp. 213-238.

A Saul, W Wagner

A fundamental equation for water covering the range from the melting line to 1273 $\mathrm{K}$ at pressures up to $25000 \mathrm{MPa}$

J. Phys. Chem., 18 (1989), pp. 1537-1565

R Knoche, D.B Dingwell, S.L Webb

Melt densities for leucogranites and granitic pegmatites: partial molar volumes for $\mathrm{SiO}_{2}, \mathrm{Al}_{2} \mathrm{O}_{3}, \mathrm{Na}_{2} \mathrm{O}, \mathrm{K}_{2} \mathrm{O}, \mathrm{Li}_{2} \mathrm{O}, \mathrm{Rb}_{2} \mathrm{O}, \mathrm{Cs}_{2} \mathrm{O}, \mathrm{MgO}, \mathrm{CaO}, \mathrm{SrO}, \mathrm{BaO}, \mathrm{B}_{2} \mathrm{O}_{3}, \mathrm{P}_{2} \mathrm{O}_{5}$, $\mathrm{F}_{2} \mathrm{O}_{-1}, \mathrm{TiO}_{2}, \mathrm{Nb}_{2} \mathrm{O}_{5}, \mathrm{Ta}_{2} \mathrm{O}_{5}$ and $\mathrm{WO}_{3}$

Geochim. Cosmochim. Acta, 59 (1995), pp. 4645-4652

K.U Hess, D.B Dingwell

Viscosities of hydrous leucogranitic melts: non-arrhenian model

Am. Miner., 81 (1996), pp. 1297-1300

N.A Frankel, A Acrivos

The constitutive equation for emulsion

J. Fluid Mech., 44 (1970), pp. 65-78

M Nowak, H Behrens

The speciation of water in haplogranitic glasses and melts determined by in situ near-infrared spectroscopy

Geochim. Cosmochim. Acta, 59 (1995), pp. 3445-3450

R.L Folk, W.C Ward

Brazos River bar: a study in the significance of grain size parameters

J. Sedim. Petrol., 27 (1957), pp. 3-26

O. Navon, V. Lyakhovsky, Vesiculation processes in silicic magmas, in: J.S. Gilbert, R.S.J. Sparks (Eds.), The Physics of Explosive Volcanic Eruptions, Geological Society, London, Spec. Publ. 145, 1998, pp. 27-50.

D.J Stein, F.J Spera

Rheology and microstructure of magmatic emulsions: theory and experiments J. Volcanol. Geotherm. Res., 49 (1992), pp. 157-174

K.V. Cashman, M.T. Mangan, Physical aspects of magmatic degassing II. Constraints on vesiculation processes from textural studies of eruptive products, in: M.R. Carroll, J.R. Holloway (Eds.), Volatiles in Magmas, Reviews in Mineralogy 30, Mineral. Soc. Am., 1994, pp. 447-478.

N.S Bagdassarov, A Dorfman, D.B Dingwell

Effect of alkalis, phosphorus and water on surface tension of haplogranite melt Am. Miner., 85 (1999), pp. 33-40 
M Alidibirov, $\mathrm{V}$ Panov

Magma fragmentation dynamics: experiments with analogue porous low-strength material

Bull. Volcanol., 59 (1998), pp. 481-489

M. Alidibirov, D.B. Dingwell, Three fragmentation mechanisms for highly viscous magma under rapid decompression, J. Volcanol. Geotherm. Res., in press.

S. Redner, Fragmentation, in: H.J. Herrmann, S. Roux (Eds.), Random Material and Processes, Statistical Models for the Fracture of Disordered Media, North-Holland, New York, 1990, pp. 321-348.

M Alidibirov, D.B Dingwell, R.J Stevenson, K.U Hess, S.L Webb, J Zinke Physical properties of the 1980 Mount St. Helens cryptodome magma Bull. Volcanol., 59 (1997), pp. 103-111

E Kaminski, C Jaupart

The size distribution of pyroclasts and the fragmentation sequence in explosive volcanic eruptions

J. Geophys. Res., 103 (1998), pp. 29759-29779

O Melnik, R.S.J Sparks

Nonlinear dynamics of lava dome extrusion

Nature, 402 (1999), pp. 37-41

B Voight et al.

Magma flow instability and cyclic activity at Soufriere Hills Volcano, Montserrat, B.W.I.

Science, 283 (1999), pp. 1138-1142 